\title{
A (DES)CONSTRUÇÃO DE GÊNERO NOS FILMES SHREK
}

\author{
CLÁUDIA MAIA \\ Universidade Estadual de Montes Claros (Unimontes) \\ RENATA SANTOS MAIA \\ Universidade Estadual de Montes Claros (Unimontes)
}

\section{RESUMO}

Este artigo compreende um estudo sobre as rupturas e permanências nas representações do feminino e do masculino através da sequência de filmes Shrek. Para tanto utilizamos abordagens dos estudos feministas e de gênero. A metodologia utilizada é a revisão bibliográfica, alguns procedimentos da análise do discurso de vertente francesa (AD), tomando por base as reflexões de Michel Foucault, a produção de sentidos no cotidiano, e a articulação entre historiografia, cinema e gênero. $O$ conceito de representação social utilizado no trabalho parte da perspectiva de Denise Jodelet; e os pressupostos que dão base ao conceito de gênero são os abordados por Teresa de Lauretis. A partir do uso dessas teorias e metodologias compreendemos que o cinema é um poderoso formador de representações sociais e de subjetivação dos gêneros. Percebemos que as fontes escolhidas são recheadas de construções sociais que atuam na constituição dos sujeitos e são importantes instrumentos pedagogizantes.

PALAVRAS-CHAVE: gênero; cinema; representações; discurso; produção de sentido.

\section{ABSTRACT}

This article includes a study on the ruptures and continuities in the representations of female and male through a sequence of Shrek films. For this purpose we use the feminist studies and gender. The concept of social representation used in the job part of the prospect of Denise Jodelet; and the assumptions that form the basis for the concept of gender mainstreaming are dealt with by Teresa de Lauretis. From the use of these theories and methodologies we understand that these media are powerful shapers of social representations and subjectivization of foodstuffs. We realized that the sources chosen are stuffed of social constructs that act in the constitution of subjects and are important pedagogical instruments.

KEYWORDS: gender; cinema; representations; discourse; meaning production. 
O cinema cresceu como campo de interesse da historiografia brasileira a partir, principalmente, da década de 1990, tornando-se um terreno fértil para problematizar o social dada a sua capacidade de atingir públicos cada vez maiores e mais diversificados, assim como de articular fatores de ordem econômica, política, cultural e estética. Esse campo cresceu também como preocupação dos estudos feministas, pois, conforme assevera Teresa de Lauretis, o cinema consiste numa importante tecnologia de gênero que, ao lado de outras tecnologias sociais e políticas, constitui sujeitos como masculinos e femininos de forma hierárquica e assimétrica. Assim, para essa autora o gênero "não é uma propriedade de corpos nem algo que existente a priori nos seres humanos", mas "'o conjunto de efeitos produzidos em corpos, comportamentos e relações sociais'" ${ }^{1}$ A construção de gênero se efetua na contemporaneidade no mesmo ritmo do passado e de forma mais evidente em espaços como a mídia. Por isso, faz-se necessário questionar e desconstruir a história, entender os mecanismos de exclusão, de constituição de discursos e os aparatos de construção social e cultural do feminino e do masculino, até para poder romper com essa visão binária. Pois, de acordo com Tânia Navarro-Swain ${ }^{2}$, é preciso conhecer os mecanismos de produção de assujeitamento ao sistema sexogênero para operar a sua desconstrução.

Em consonância com tal perspectiva, este artigo objetiva discutir as construções de gênero na série de filmes de animação infantil Shrek, procurando entender as permanências e rupturas operadas nos personagens desse tipo de cinema, nos sentidos historicamente associados ao feminino e ao masculino. A escolha dessa série deve-se à percepção de uma modificação na elaboração das animações cinematográficas, que passaram a inserir em seus roteiros problematizações da contemporaneidade sobre as questões de gênero.

$O$ enredo dos filmes aqui estudados é baseado em um conto homônimo do livro de William Steig. Neste conto contemporâneo, questionam-se os valores antigos dos contos de fadas, como o maniqueísmo que associa beleza e bondade em oposição à feiúra e à maldade, além da crítica aos sujeitos da nobreza.

Outros estudos já se ocuparam dos filmes Shrek. Entre eles podemos destacar a tese de doutorado de Liliane Machado, E a mídia criou a mulher. como a TV e o cinema constroem o sistema de sexo/ gênero, que empreende uma análise das matrizes discursivas sobre as mulheres a partir das figuras femininas presentes nos filmes e desenhos por ela escolhidos, entre os quais estão Shrek e Shrek 2. O que a abordagem do presente estudo traz de contribuição, em relação aos anteriores, é a problematização que apresenta de outros temas como maternidade, casamento, família e valores patriarcais e que, por isso mesmo, fazem parte dos estratos mais profundos, altamente naturalizados na sociedade, cuja ultrapassagem demanda tempo e esforço.

\footnotetext{
${ }^{1}$ LAURETIS, Teresa de. As tecnologias de gênero. In: HOLLANDA, H. B. Tendências e impasses: o feminismo como crítica da cultura. Rio de Janeiro: Rocco, 1994, p. 208.

2 NAVARRO-SWAIN, Tania. Identidade pra te quero? Disponível em: <http://www.tanianavarroswain.com.br/brasil/identidade\%20p\%20q\%20te\%20qyero.htm>.
} 
Na série de filmes Shrek, são feitas diversas paródias com cenas clássicas de outras produções bastante conhecidas como Matrix, As panteras e Missão Impossível, além de inferências provocativas aos tradicionais contos infantis e a algumas animações da Disney, como Branca de Neve e os sete anões e $A$ Bela Adormecida. Traz apelos visuais e sonoros além dos elementos estéticos que promovem uma identificação ainda maior dos espectadores com os filmes.

O primeiro filme da série, lançado em 2001, conquistou o Oscar de melhor animação; o segundo, em 2004, alcançou um recorde de bilheteria. Em 2007, foi lançado Shrek terceiro, e em 2010 o quarto filme da série - Shrek para Sempre - foi confirmado como o último da franquia. Mas, além da saga de Shrek nestes quatro filmes, vários especiais foram produzidos durante esse tempo como Shrek 3D (2003), Shrek especial de Natal(2007), O susto de Shrek (2010), O natal shrektacular do Burro (2010) e Gato de Botas: a história de um matador de ogros. Todos derivados do sucesso alcançado pelos primeiros longas-metragens. Cada um destes filmes possuiu diferentes diretores, e essa recorrente troca é um exemplo do chamado "filme de produtor", onde a figura do diretor não interessa tanto para os estúdios ${ }^{3}$.

A história dos filmes constitui-se em um conto de fadas às avessas, Shrek é o anti-herói que cativa o público por não ter preocupação alguma em ser agradável; é egoísta, mal-cheiroso, não tem bons modos (no início do primeiro filme já aparece soltando peidos e arrotos) e com sua aparência verde e corpulenta causa repulsa nas demais personagens, fazendo inclusive murcharem as flores e vergarem as árvores por onde passa. Até mesmo o motivo que o leva a salvar a princesa gira em torno de interesses próprios: ao ver seu pântano invadido pelos vários personagens das histórias infantis e perturbado o seu sossego, Shrek vai em busca da princesa Fiona, condição imposta por Lord Farquaad para receber as criaturas mágicas novamente em seu reino, e devolver a quietude aos domínios do ogro.

Os filmes apresentam ainda personagens singulares como uma FadaMadrinha ambiciosa; um príncipe pedante, interesseiro e covarde (Farquaad) e outro vaidoso, artificial e extremamente preocupado com a aparência (Encantado); um Lobo Mau que passa todo o tempo vestido de vovozinha e o Pinóquio que gosta de usar roupas íntimas femininas; além do dragão que vigia o castelo, representante de força e ferocidade, tradicionalmente constituinte do gênero masculino, e na obra trata-se de uma fêmea que acaba se apaixonando pelo Burro, companheiro de aventuras de Shrek.

Outro momento de ruptura com os tradicionais contos infantis e noções de gênero se dá no resgate da princesa Fiona, que havia idealizado tal momento como sublime, onde o cavalheiro Ihe recitaria um poema épico, a tomaria nos braços e desceria por uma corda até sua bela montaria. Mas Shrek, preocupado em terminar logo sua tarefa, a sacode violentamente para acordá-

\footnotetext{
${ }^{3} \mathrm{O}$ primeiro filme foi dirigido por Andrew Adamson e Vicky Jenson. O segundo sofreu 0 acréscimo de Kelly Asbury e Conrad Vernon. Shrek terceiro foi dirigido por Chris Miller e Raman Hui; e o quarto, Shrek Para Sempre, por Mike Mitchell, com roteiro de Tim Sullivan.
} 
la do suposto sono e apenas a coloca sobre os ombros e sai correndo para fugir do dragão, sem romantismo.

A Princesa Fiona, apesar de apresentar, a princípio, um discurso idealizado em relação ao amor e ao cavaleiro que a salvaria, também é uma mulher bastante prática e independente, luta contra um grande número de homens sozinha, come ratos no espeto e até arrota, deixando Shrek e o Burro perplexos diante da sua postura auto-suficiente, bem diferente das princesas apresentadas nos contos tradicionais, que eram geralmente frágeis, românticas e dependentes.

Em Shrek Terceiro é feita uma interdiscurso com o movimento feminista, quando as princesas se unem para lutar contra o Príncipe Encantado. Nessa cena, a rainha derruba as paredes da prisão usando golpes com a cabeça, Cinderela afia seus sapatinhos de cristal (para utilizá-los como arma), e as demais princesas rasgam as mangas e barras dos vestidos, queimam um sutiã, como forma de protesto, e vão à luta para derrubar o usurpador do poder no Reino Tão Tão Distante.

Por ter sofrido vários desdobramentos, a história de Shrek e Fiona mostra o que acontece depois do casamento e do "felizes para sempre", problematizando as dificuldades do relacionamento e também a chegada dos filhos. No filme são abordadas ainda questões como alteridade, a intolerância ao diferente, necessidade de se enquadrar em padrões de beleza e comportamento fixados pela sociedade.

Também são apresentadas, nessa nova configuração das histórias infantis, diferentes identidades de gênero e formas plurais de vivenciar a sexualidade, como é o caso das personagens transgêneras Dóris e Mabel, originalmente as irmãs feias da Cinderela. Tudo isso pode ser entendido como reflexo das modificações vividas na contemporaneidade, e que ganham uma visibilidade maior a partir do impacto da mídia e dos novos mecanismos tecnológicos.

Ao evocar a memória discursiva e também questões relativas ao relacionamento conjugal, que aparecem no terceiro filme e com maior ênfase no seguinte (Shrek para sempre), fica claro que eles, embora sejam apresentados como um produto destinado às crianças, falam também ao público adulto, pois alguns códigos presentes nas suas mensagens não produzem sentidos ao público infantil. Este não absorve a quantidade de informações que remetem a um conhecimento prévio ou a uma vivência que ainda não experimentaram.

No primeiro filme um fato inusitado inverte a lógica esperada pelo público. No momento em que Fiona e Shrek se beijam, ao invés de assumir definitivamente a aparência humana, provável resultado do beijo do amor verdadeiro, a princesa toma a forma de uma ogra, contraponto com outros contos infantis, como $A$ Bela e a Fera, onde se dá o oposto e a Fera se torna humano novamente quando o encanto se quebra; e no filme $A$ pequena Sereia, quando Ariel assume a forma humana para viver seu amor com o Príncipe Eric.

Esse arranjo final sugere também que o relacionamento amoroso só funciona entre iguais. Assim, os pares assimétricos: mulher/fera, sereia/homem e princesa/ogro não são possíveis, necessitando que um dos parceiros se 
transforme para harmonizar a imagem do casal. Por outro lado há a relação entre o Burro e o Dragão, que mesmo não pertencendo à mesma espécie vivem um relacionamento feliz e harmonioso. Esse contraste faz parte das rupturas e continuidades apresentadas nos filmes.

Tomamos esses filmes como documentos investidos de relações de poder, são práticas discursivas que produzem efeitos, sentidos. Seguindo o que Michel Foucault diz, entendemos que o documento deve ser encarado como uma materialidade construída por diversas camadas sedimentadas de interpretações; não é uma matéria inerte com a qual se reconstrói o passado4.

E foi com o intuito de analisar as camadas discursivas presentes nos enunciados dos filmes que nos lançamos a essa empreitada. Para tanto, utilizamos como metodologia alguns procedimentos da Análise do Discurso de vertente francesa que considera o discurso no conjunto das práticas que constituem a sociedade e que não se encerra, mas está em constante fluxo, pois como afirma Eni Orlandi,

a análise do discurso não estaciona na interpretação, trabalha seus limites, seus mecanismos, como parte dos processos de significação. Também não procura um sentido verdadeiro através de uma chave de interpretação. Não há essa chave, há método, há construção de um dispositivo teórico. Não há uma verdade oculta atrás do texto. Há gestos de interpretação que a constituem e que o analista com seu dispositivo, deve ser capaz de compreender ${ }^{5}$.

O conceito de representação social utilizado neste estudo parte da perspectiva de Denise Jodelet que a concebe como fenômenos complexos em constante construção no meio social, "[...] uma forma de conhecimento, socialmente elaborada e partilhada, com um objetivo e concorrendo para a construção de uma realidade comum a um conjunto social ${ }^{\prime \prime}$. Jodelet sublinha, ainda, que um dos locais onde é possível perceber essas representações sociais são os meios de comunicação.

Ainda com o objetivo de compreender os sentidos produzidos a partir das cenas e dos diálogos estabelecidos nos filmes utilizamos os estudos sobre as práticas discursivas e a produção de sentidos no cotidiano, a partir da compreensão de que o sentido é uma construção social, um empreendimento coletivo e interativo ${ }^{7}$. Em vista dessas concepções, passamos à análise dos personagens masculinos e femininos presentes nos filmes.

\footnotetext{
${ }^{4}$ FOUCAULT, Michel. $A$ arqueologia do saber. Rio de Janeiro: Forense-Universitária, 1987, p. 7.

${ }^{5}$ ORLANDI. Eni. Análise do discurso: princípios e procedimentos. São Paulo: Pontes, 2002, p. 26.

${ }^{6}$ JODELET, Denise. Representações sociais: um domínio em expansão. In: JODELET, Denise (Org.). Representações Sociais. Rio de Janeiro: Eduerj, 2001, p. 22.

7 SPINK, Mary Jane; MEDRADO, Benedito. Produção de sentido no cotidiano: uma abordagem teórico-metodológica para análise das práticas discursivas. In: SPINK, Mary Jane (org). Práticas
} 


\section{Representações femininas}

Buscando observar as rupturas e permanências contidas nos filmes Shrek, observamos várias representações que remetem a imagens tradicionais de mulheres, como a da maternidade. As personagens femininas mais significativas, com exceção das princesas Disney, são ou se tornam mães no decorrer das sequências: Fiona, Rainha Lílian, Dragão e Fada Madrinha. E para cada uma delas são agregados perfis que produzem sentidos ligados a alguns tipos de mães que percebemos nos discursos do cotidiano: a zelosa, a culpada e a superprotetora. Mas, como os filmes buscam romper com os contos tradicionais, também temos representações femininas mais autônomas como a de líder e da guerreira.

Ao categorizar essas representações tradicionais e as mais autônomas partimos da explicação dada por Mary Jane Spink e Vera Mincoff Menegon de que tal ação é uma prática social que faz parte da condição humana e por isso

as ideias com as quais convivemos, as categorias que usamos para expressá-las e os conceitos que buscamos formalizar são constituintes de domínios diversos (da religião, da arte, da filosofia, da ciência) de grupos que nos são mais próximos (família, escola, comunidade, meio profissional etc.) e da mídia em geral ${ }^{8}$.

Fiona, personagem feminina de maior destaque, passa por várias transformações na sua representação dentro dos filmes, e possui uma dupla forma: a humana e a ogra. A princípio, ela nos é apresentada como uma donzela em perigo, esperando o seu príncipe salvador. Mas logo percebemos que se trata de uma princesa irreverente, pelo modo de se portar e se expressar quando Shrek chega para salvá-la.

Enquanto o ogro está preocupado em fugir do dragão, a princesa se ocupa em tentar encaixar o momento aos moldes dos contos de fadas tradicionais, muito mais para seguir um modelo de princesa e um roteiro convencional, que não condiz com seu espírito altivo, do que por desejar que seja assim. Mas não consegue sustentar esse teatro por muito tempo.

Fiona: Vós devíeis me tomar em vossos braços, pular pela janela e descer por uma corda até a vossa bela montaria. Shrek: Teve muito tempo para planejar isso, não teve? Fiona: Hum, hum!

(...)

discursivas e produção de sentidos no cotidiano. Rio de Janeiro: Centro Edelstein de Pesquisas sociais, 2013, p. 22.

${ }^{8}$ SPINK, Mary Jane; MENEGON, Vera Mincoff. A pesquisa como prática discursiva: superando os horrores metodológicos. In: SPINK, Mary Jane (org). Práticas discursivas e produção de sentidos no cotidiano. Rio de Janeiro: Centro Edelstein de Pesquisas sociais, 2013, p. 42. 
Fiona: Mas nós devemos viver esse momento. Você poderia recitar um poema épico para mim, um cancioneiro, um soneto, uma estrofe, qualquer coisa.

Shrek: Eu acho que não.

Fiona: Bom, pelo menos posso saber qual é o nome do meu campeão?

Shrek: Ah... Shrek.

Fiona (estendendo um lenço): Sir, Shrek. Rezo para que aceite este favor como prova de minha gratidão.

(Ouve-se um rugido)

Fiona: Você não matou o dragão?

Shrek: 'Tá' na minha lista. Agora vamos.

Fiona: Mas não está certo. Você devia ter entrado com a espada em uma mão e na outra um estandarte, foi o que todos os outros fizeram.

Shrek: É, logo antes de ficarem torrados.

Fiona: Isso não vem ao caso. Espera, pra onde vamos? A saída é pra lá.

Shrek: Bom, eu quero tirar o meu da reta.

Fiona: Mas que tipo de cavalheiro é você?

Shrek: Um tipo único ${ }^{9}$.

Esse trecho do diálogo entre Fiona e Shrek faz uma sátira aos contos tradicionais, mostrando 0 inconveniente dos formalismos criados para ornamentar o encontro dos protagonistas nessas narrativas. Até mesmo o tipo de linguagem utilizada por Fiona, um rebuscamento forçado, representa esse escárnio pelos romances convencionais. E apresenta as características que assinalam Shrek como o anti-herói que age em nome de interesses próprios e não tem preocupação em se destacar com atitudes de bravura, tanto que ele consegue se livrar do dragão não por meio do enfrentamento corajoso, mas utilizando de artimanhas e habilidade de raciocínio. É também uma forma de mostrar que o feminino é identificado com o romantismo, enquanto o masculino com a praticidade e a razão.

Fiona reproduz esses discursos porque foi assujeitada nesse sentido, acreditando também que ser ogra era algo ruim, que somente o beijo do amor verdadeiro a libertaria dessa condição e que nada podia fazer além de esperar por ele. Em seu diário de adolescente ela registra alguns desses ensinamentos: "a mamãe disse que quando eu tiver idade, um lindo príncipe encantado irá me salvar da torre e me trazer de volta para a minha família. E vamos viver felizes para sempre ${ }^{\prime 10}$.

A esses escritos seguem-se uma ilustração feita por Fiona onde aparecem ela, um príncipe e três crianças, e repetidos dizeres de "Senhora Fiona Encantado". Em vários momentos da história ela reitera esse discurso e também o de como deve ser uma princesa:

\footnotetext{
${ }^{9}$ SHREK, PDI/DREAMWORKS, 2001.

${ }^{10}$ SHREK, PDI/DREAMWORKS, 2004.
} 
Eu sou uma princesa e não é assim que uma princesa deve parecer [se referindo à identidade ogra] (...) Olha bem pra mim, Burro. Pensa bem, quem poderia amar um monstro tão nojento e feio. Princesa e feiúra não combinam. (...) Minha única chance de viver feliz para sempre é me casar com meu verdadeiro amor. É assim que tem de $\operatorname{ser}^{11}$.

O trecho em destaque deixa claro que Fiona condiciona sua felicidade ao matrimônio e se conforma com esse destino simplesmente porque "é assim que tem de ser", ela é uma princesa, uma mulher, e é isso que a vida reserva para o gênero feminino. É uma concepção determinista diante da qual ela não vê saída.

Embora a Princesa Fiona tenha apresentado um discurso tradicional e idealizado sobre seu salvador e o momento sublime desse encontro, ela também tem seu lado impetuoso, e se mostra em outras ocasiões como uma mulher de muita personalidade, que conhece golpes marciais e os utiliza para se defender, assim ela co-participa do seu salvamento. Essas habilidades são testadas no caminho de volta para Duloc, quando Fiona é capturada por Robin Hood, que acreditava estar a princesa em perigo. Então, utilizando técnicas de luta semelhante às usadas no filme Matrix, Fiona desfere sozinha vários golpes contra Robin e seus companheiros. Na cena seguinte é feito um interdiscurso com a história da Branca de Neve. Fiona começa a cantarolar e é acompanhada de um pássaro, mas, ao entoar uma nota muito aguda, a ave explode e a princesa rouba seus ovos para comer junto com Burro e Shrek.

É emblemático o fato de que mesmo sabendo lutar, Fiona não tenha tentado se livrar do dragão e fugir do castelo. Ao invés disso, ela aguardou, pacientemente, seu salvador - aquele que iria livrá-la da maldição depois do casamento e do beijo do amor verdadeiro. Mesmo possuindo capacidade intelectual e habilidades físicas, ela espera que um agente externo masculino traga a solução para os seus problemas e para que seu destino seja cumprido. Isso acontece devido às representações de gênero constituídas que atribuem ao homem a posição de sujeito ativo que toma as decisões, por oposição à passividade feminina.

Mas sugere também, nesse caso, que a prisão não é apenas a torre, mas o corpo de ogra que ela assume ao cair da noite. $O$ que ela espera é livrar-se desse corpo/maldição, e para isso precisa assumir um comportamento de mulher passiva, a espera de um salvador, logo do amor verdadeiro, como se, para as mulheres serem felizes e amadas fosse necessário um tipo de comportamento baseado na passividade e submissão, e um corpo que obedece ao padrão estético idealizado: magro e belo. Entretanto, o desfecho é outro, Fiona vai encontrar a felicidade e o amor verdadeiro com o corpo de ogra e com uma imagem do feminino, comportamento e postura, ligada à valentia, destemor e independência.

${ }^{11}$ SHREK, PDI/DREAMWORKS, 2001. Grifos nossos. 
O dilema vivido por Fiona ilustra o conflito de várias mulheres que oscilam entre o que é colocado socialmente como meta e ideal de beleza, inclusive por elas mesmas, encarnado na figura de Fiona humana, com sua silhueta delgada e curvilínea, e o pesadelo dos quilos a mais que as atormenta representado pela imagem de Fiona ogra.

No segundo filme Fiona é domesticada, passando a cumprir o papel tradicional de esposa. Toda a impetuosidade apresentada pela princesa no primeiro filme praticamente desaparece neste segundo, e ela assume mesmo a postura e o comportamento que tradicionalmente se espera de uma mulher casada: dócil, um tanto submissa e resignada, ela não mais se impõe como no primeiro. Tal comportamento adotado por Fiona prevaleceu durante todo o século XIX, atribuindo às mulheres as características de delicadeza e fragilidade, e esperando-se delas obediência. A mulher ou era vista como reprodutora ou, ao fugir dessa função social, prostituta e transgressora da moral.

Dentro dessa concepção patriarcal, a maternidade não é questionada ou vista como uma opção para a mulher, mas algo que faz parte da sua natureza. Da mesma forma acontece com Fiona, por isso chega o seu momento de vivêla. Essa ocasião é retratada no filme como uma etapa previsível na vida da princesa, uma vez que já estava casada. Conforme argumenta Tânia Swain "a instituição social do casamento e seu corolário, a maternidade, aparecem como elementos constitutivos do 'ser mulher' enquanto locus ideal do feminino"12. Fiona tenta preparar o marido para receber a novidade, já que ele se mostra avesso a essa experiência e chega a se lamentar: "eu não posso acreditar que vou ser pai. Como isso foi acontecer?". Shrek deixa a entender que não precisam de filhos, e diz a Fiona para serem racionais e práticos, pois: "os bebês só comem, fazem cocô e choram, aí choram quando fazem cocô, e fazem cocô quando choram" e sendo um bebê ogro seria um "mega choro e um mega cocô". O que inferimos da cena e das falas é que a vontade de ter filhos é exclusiva da mulher, bem como a necessidade de formar uma família.

Apesar de grávida, Fiona não se mostra frágil, ajudando a salvar o reino e o próprio Shrek das investidas do Príncipe Encantado. Fiona é uma personagem paradoxal, pois evoca tanto representações tradicionais do feminino, quanto da mulher moderna, emancipada e livre em seus movimentos e condutas. Assim, ao mesmo tempo em que reforça alguns sentidos tradicionais, rompe com outros como na cena em que aparece se barbeando ao lado de Shrek, assinalando que mulheres e homens podem desenvolver as mesmas atividades sem que isso se constitua em um marcador da identidade sexual e de gênero.

\footnotetext{
${ }^{12}$ NAVARRO-SWAIN, Tania. A invenção do corpo ou "a hora e a vez" do nomadismo identitário. Disponível em: http://www.tanianavarroswain.com.br/chapitres/bresil/espelho,espelho.htm. Acesso em 18 set. 2012.
} 
No quarto filme há uma tentativa de retomar a imagem de Fiona como figura de liderança e independência. Ela reaparece como uma guerreira que comanda uma legião de ogros, organiza uma revolução e traça estratégias de combate com o objetivo de tomar o poder no reino e libertar os ogros escravizados. A nova posição que Fiona passou a ocupar como líder de um exército de ogros, todos do gênero masculino, indica que ela só pôde alcançar tal posto porque não se casou nem teve filhos. No entanto, ela parece infeliz e amargurada mesmo sendo admirada dentro do clã. O fato de ter precisado salvar a si mesma da prisão em que vivia a transformou em uma mulher dura e implacável.

Algo semelhante acontece com o Dragão fêmea também neste filme, por não ter vivido seu romance com o Burro e nem ter tido filhotes com ele, ela surge como uma fera indomada e perigosa. Isso reforça a ideia do matrimônio como um mecanismo disciplinador da conduta feminina.

As imagens a seguir expressam uma nítida mudança na aparência da ogra com o objetivo de dar a ela uma identidade não mais de princesa frágil e delicada, mas de imponente guerreira. A imagem da direita, com formato em delta para dar destaque propositalmente à Fiona, evidencia algumas alterações na sua aparência a fim de representá-la como comandante da tropa: o clássico vestido longo é substituído por um conjunto composto de blusa de couro e uma saia xadrez assimétrica para facilitar os movimentos corporais; as delicadas sapatilhas são trocadas por botas feitas de couro e de cano alto próprias para combates; os cabelos aparecem soltos e ao vento para dar uma impressão de liberdade e de que nos campos de batalha não há tempo para ficar cuidando do penteado, abandonando a tradicional trança usada em todos os filmes anteriores, sendo que na imagem é o único elemento que transmite a impressão de movimento; por fim, um colar com dentes de animais aparece no lugar da delicada gargantilha com pingente em forma de coração, que antes enfeitava o pescoço da princesa.
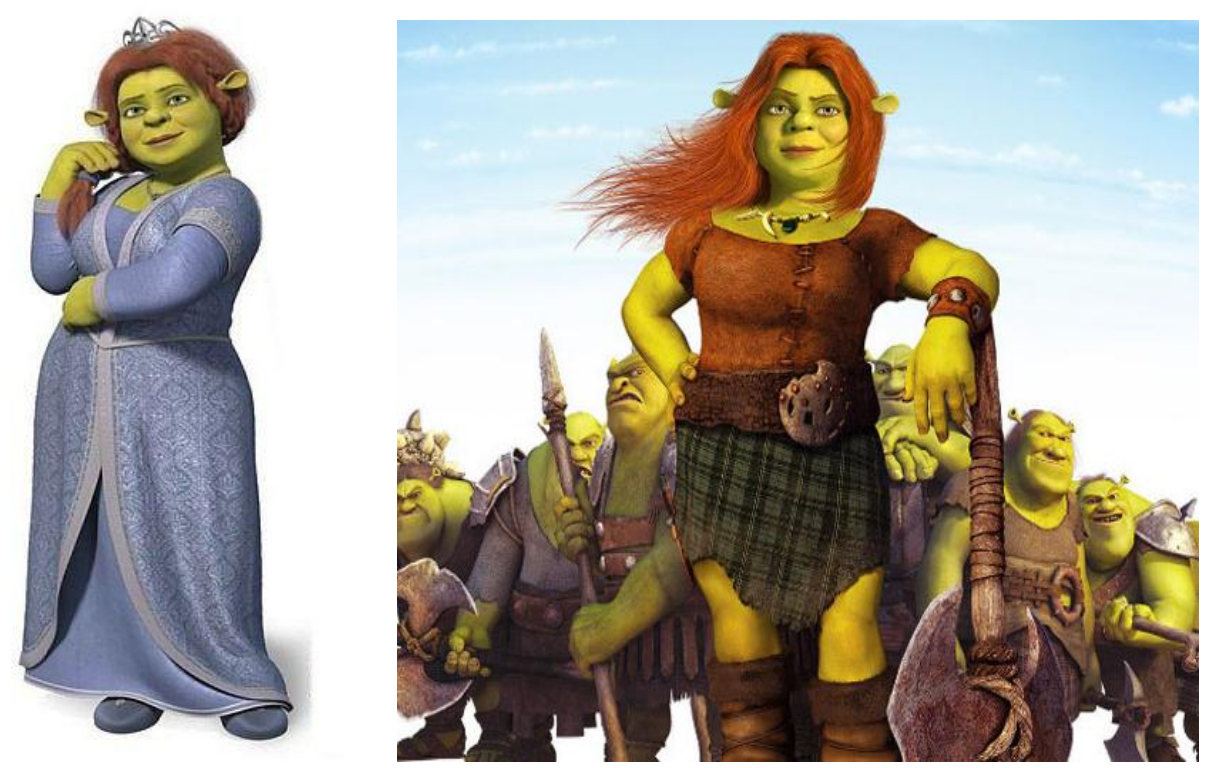

Imagem 1: Fiona princesa e Fiona guerreira. Fonte: http://jeniss.blogspot.com.br. Acesso em 23 de janeiro de 2014. 
Essa multiplicidade de papéis desempenhados por Fiona tem a ver com a constituição da mulher contemporânea que, mesmo sem ter conseguido se desvincular da maternidade como destino biológico, também não fica mais restrita somente ao espaço doméstico e quer se ver representada de maneiras diversas.

A Fada-Madrinha, em Shrek Terceiro, também é mãe, característica que não aparece em nenhuma referência a essa personagem nos contos clássicos ou nas suas adaptações para o cinema. As fadas são seres comumente reivindicados nas histórias infantis como cheias de boas intenções, mas no filme é uma senhora interesseira e um tanto histérica. É uma mãe excessivamente cuidadosa e preocupada, que mima o filho, Príncipe Encantado, projetando para ele um futuro como rei. Para tanto, ela utiliza várias artimanhas para realizar o destino que havia traçado para o filho.

A etimologia da palavra "fada" vem de fata ${ }^{13}$ que em latim significa destino, e é precisamente nessa questão que essas criaturas costumam intervir como faz esta personagem nos filmes. Longe de ser a senhora bondosa das histórias convencionais, essa Fada Madrinha é uma empresária da magia, possui a sua fábrica de poções e explora seus funcionários. É por meio da chantagem que ela tenta galgar para o filho um lugar de destaque na sociedade. A Fada Madrinha figura aqui como uma das representações de mãe que assinalamos anteriormente: a superprotetora que estraga os filhos com 0 excesso de mimos.

O dragão dos contos de fadas, por sua vez, "nos aparece essencialmente como um guardião severo ou como um símbolo do mal e das tendências demoníacas. Ele é, na verdade, o guardião de tesouros ocultos, e, como tal, o adversário que deve ser eliminado para se ter acesso a eles ${ }^{\prime 14}$. Como a proposta dos filmes Shrek parece ser de subverter a lógica dos contos de fadas, o dragão que aparece na história além de ser uma fêmea, possui bons sentimentos e, enquanto guarda a princesa no castelo, espera, ela própria, por seu grande amor. Percebendo no Burro o seu par romântico, é ela quem toma a iniciativa de conquistá-lo. O Dragão é tratado como uma integrante social do grupo de mulheres nos filmes, participa dos momentos de descontração como o chá de bebê de Fiona e das festas de encerramento dos filmes. Da relação entre ela e o Burro, nascem muitos filhotes, o que também a constitui como mãe. É ela que fica com eles, enquanto o Burro sai para se aventurar com Shrek. É, portanto, uma mãe zelosa que vive para os filhos e mais uma personagem feminina que se torna esposa e mãe durante a sequência dos filmes, e, ao contrário do burro falador, ela não tem fala.

\footnotetext{
${ }^{13}$ CHEVALIER, Jean. Dicionário de símbolos - mitos, sonhos, costumes, gestos, figuras, cores e números. Rio de Janeiro: José Olympio, 2009, p. 415.

${ }^{14}$ Id. Ibidem, p. 349.
} 
A Rainha Lílian em todos os filmes é representada como uma esposa obediente e mãe carinhosa. Sua maior preocupação é com a felicidade da filha e o bem-estar do marido. Ela tenta ser conciliadora quando Fiona apresenta 0 marido ogro aos pais e não consegue a aceitação da família. No entanto, em nenhum momento, mesmo estando a favor da filha, contraria o marido intransigente:

Rei Harold: Eu não acredito nisso, Lílian. Francamente, ele é o ogro, não eu.

Rainha Lílian: Harold, eu acho que você está levando isso a nível pessoal. A escolha foi da Fiona

Rei Harold: Sim, mas ela deveria ter escolhido o príncipe que escolhemos para ela. Olha, você espera que eu dê a minha bênção a essa... essa... coisa?

Rainha Lílian: A Fiona espera, e ela nunca perdoará se você não der. Eu não quero perder a nossa filha novamente, Harold. Ora, você se comporta como se o amor fosse totalmente previsível. Não se lembra de quando nós éramos jovens e oh... costumávamos passear pelo lago com os lírios se abrindo...

Rei Harold: Oh, nosso primeiro beijo... não é a mesma coisa! Acho que você não percebeu que nossa filha se casou com um monstro!

Rainha Lílian: Deixe de fazer tanto drama ${ }^{15}$.

Lílian adota um dos comportamentos que apontamos no início: a mãe culpada. Ela demonstra em todos os filmes não ter concordado com a decisão de trancar Fiona em uma torre por causa da sua dupla forma - humana e ogra. Mas também não conseguiu ir contra a decisão do marido e por isso se sente culpada, procurando remediar as situações de conflito. Pelo diálogo estabelecido entre o casal, percebemos que a tentativa de repreender o marido culmina em uma lembrança de quando eram jovens e apaixonados, desvirtuando o assunto inicial da discussão.

Percebemos que as representações femininas apresentadas nesse tipo de produção sofreram sem dúvida uma revisão, acrescentando-se a elas elementos como força, coragem, capacidade de liderar e independência, características antes atribuídas somente aos personagens do gênero masculino. Por outro lado, as representações de mãe e esposa ainda estão muito presentes e se perpetuam no discurso social através da repetição até serem consideradas como uma condição "natural" do feminino como vimos ao longo destes filmes e como acontece em tantas outras mídias. Deste modo,

o desejo de ter filhos biológicos continua a compor o quadro de um feminino perfeito, pois as mudanças na ordem social parecem fazer-se de maneira sempre ambígua: as grades de

${ }^{15}$ SHREK, PDI/DREAMWORKS, 2004. 
interpretação do mundo não se transformam de uma só vez e as representações sociais de gênero delas são constitutivas ${ }^{16}$.

Outro elemento a ser destacado em todos os filmes da série, a exceção do último, é que é quem sai para se aventurar e explorar lugares e situações diversas é o Shrek, acompanhado de outros personagens masculinos: o Burro e o Gato de Botas. Enquanto isso, Fiona fica no castelo junto com as demais personagens femininas ou com sua família, delimitando a tradicional separação entre os espaços público, associado ao masculino, e o doméstico, associado ao feminino. Somente no último filme da sequência, em que Fiona não se casou porque Shrek não foi salvá-la, é que ela ultrapassa os limites do doméstico e se torna líder de uma rebelião.

Conforme sublinham Spink e Medrado:

a compreensão das práticas discursivas deve levar em conta tanto as permanências como, principalmente, as rupturas históricas, pela identificação do velho no novo e vice-versa, o que possibilita a explicitação da dinâmica das transformações históricas e impulsiona sua transformação constante ${ }^{17}$.

Compreendemos, assim, que essas representações não são totalmente novas e desvinculadas da tradição. Nesse caso, mesmo produzindo outros sentidos sobre o feminino, antigos são evocados e muitas vezes reforçados.

\section{Representações masculinas}

Ao contrário das animações tradicionais, em que se viam como representações masculinas apenas o príncipe e, às vezes, o pai da princesa, nas animações mais recentes, esses personagens se diversificaram. Nas fontes usadas neste artigo, identificamos alguns dos perfis que surgiram mais recentemente.

Shrek, protagonista e anti-herói da série que levam seu nome, tem um tipo físico alegórico: é careca, verde, corpulento e se veste como um plebeu, seus gestos são rudes, não possui traquejo social e não segue regras de etiqueta. Para deixar bem claro que este é um personagem atípico, seus produtores e diretores já no princípio do filme colocaram-no tomando banho de lama, escovando os dentes com a gosma de uma lagarta, se divertindo

\footnotetext{
${ }^{16}$ NAVARRO-SWAIN, Tania. $A$ invenção do corpo ou "a hora e a vez" do nomadismo identitário. Disponível em: http://www.tanianavarroswain.com.br/chapitres/bresil/espelho,espelho.htm. Acesso em 18 set. 2012.

${ }^{17}$ SPINK, Mary Jane; MEDRADO, Benedito. Produção de sentido no cotidiano: uma abordagem teórico-metodológica para análise das práticas discursivas. In: SPINK, Mary Jane (org). Práticas discursivas e produção de sentidos no cotidiano. Rio de Janeiro: Centro Edelstein de Pesquisas sociais, 2013, p. 41.
} 
espantando os outros seres da floresta e comendo larvas. Ele tenta a todo custo, manter as demais criaturas longe dos seus domínios através de avisos espalhados por toda parte dando conta de que ele é um ogro terrível e perigoso.

Os ogros dos contos populares normalmente são retratados como vilões, seres asquerosos e devoradores sedentos de carne humana. Ao colocar um ogro como protagonista, o filme inverteu o papel do herói e do monstro. Para Mirian Ramos, "mostrar um personagem marginalizado como protagonista é dar voz e valorizar as diferenças, permitir que o outro mostre seu universo ao invés de julgá-lo precipitadamente por meio de critérios subjetivistas" ${ }^{18}$.

Shrek é retratado ao longo das sequências sob diversas representações, inclusive de marido e pai, o que configura uma novidade nas animações destinadas ao público infantil. Ele próprio se percebe como um ser múltiplo: "Há mais nos ogros do que se pensa. (...) Os ogros são como as cebolas, possuem camadas"19.

Os filmes alcançaram grande sucesso não somente pelo humor e a fantasia como forma de atrair o público, mas porque partem de experiências cotidianas das pessoas, seus medos e desejos. Assim, em diversos momentos, Shrek enfatiza o preconceito que sofre por ser um ogro:

Burro: Ei, qual é o problema, Shrek? O que tem contra todo mundo, afinal?

Shrek: Não sou eu que tenho problemas, é o mundo que parece ter um problema comigo. As pessoas olham pra mim e (dizem) "ah, socorro! Corram! Um ogro enorme e horrível!"Ah, elas me julgam antes de me conhecerem. É por isso que estou melhor sozinho ${ }^{20}$.

Esse enunciado sugere que a aparência física é considerada um aspecto importante para a aceitação e convívio social, e o indivíduo que não se enquadra em um padrão estético aceitável, encontra dificuldade para viver em sociedade.

No decorrer da história contada nos quatro filmes, Shrek vai se tornando mais autoritário. No último filme, por exemplo, o casal de ogros se desentende porque Shrek não consegue se adaptar à rotina e à quantidade de afazeres da casa. Os aldeões o chamam de bobalhão e dizem que ele não é mais um ogro de verdade. $O$ sentido produzido é de que o casamento e a paternidade 0 moldaram. Por isso ele diz que quer ser como o antigo ogro, temido e feroz, ou seja, ele quer recuperar sua virilidade perdida para que "o mundo volte a fazer sentido":

\footnotetext{
${ }^{18}$ SANTOS, Miriam Ramos. $O$ "diferente" e o "feminino" em Shrek: uma análise das formações discursivas. Dissertação (Mestrado em Estudo de Linguagens) - Universidade do Estado da Bahia, Salvador, 2009, p. 43.

${ }^{19}$ SHREK, PDI/DREAMWORKS, 2001.

${ }^{20}$ SHREK, PDI/DREAMWORKS, 2001.
} 
Fiona: Eu não acredito nisso.

Shrek: Ah, nem me fale. Esse pessoal...

Fiona: Eu não estou falando deles. Estou falando de você. É assim que quer se lembrar do primeiro aniversário dos seus filhos?

Shrek: Ah, que ótimo! Agora a culpa é minha.

Fiona: É! Mas vamos deixar para discutir isso depois da festa, em casa.

Shrek: Você se refere àquela atração turística em que a gente mora: "olha pra ele, o ogro dançarino (imitando um aldeão). Não tenham medo, ele não morde". Eu já fui um ogro. Agora eu sou uma piada esverdeada.

Fiona: 'Tá' bem. Talvez você não seja o ogro que costumava ser, mas isso não é tão ruim assim.

Shrek: Você não poderia entender. Você nem ogra é de verdade, passou metade da vida num palácio.

Fiona: $\mathrm{E}$ a outra metade trancada numa torre.

Shrek: Olha, eu só quero que as coisas voltem a ser como eram antigamente. Quando os aldeões tinham medo de mim e eu podia tomar meu banho de lama em paz. Quando eu fazia 0 que eu bem entendia na hora em que eu queria. Quando o mundo fazia sentido.

Fiona: Quer dizer antes de você me resgatar da torre do dragão?

Shrek: É isso aí! (Grifos nossos) ${ }^{21}$.

Os trechos em destaque indicam que Shrek quer se ver livre das tarefas domésticas porque isso o faz ser motivo de piada diante das pessoas, principalmente de outros homens. Ninguém tem medo de um ogro que cuida de crianças e da casa, pois isso é visto como um serviço feminino. E para ter resgatada a sua masculinidade ele precisa voltar a ser o antigo ogro: solteiro e sem obrigações, para fazer tudo o que quiser, na hora em que quiser. Na ótica de Shrek, o mundo só faz sentido se ele puder impor suas vontades: "se ela acha que eu vou voltar rastejando para pedir desculpas, pode tirar o 'cavalinho da chuva'. Ela não manda em mim. Eu sou um ogro, e eu não vou pedir desculpas por agir como um"22, ou seja, ele é um macho e como tal tem o direito de falar o que quiser, mesmo que isso possa ferir os sentimentos da esposa. Shrek utiliza-se, portanto, de um discurso machista recorrente no imaginário social que constrói a ideia de que agir com grosseria é natural. Por isso, entendemos que

um enunciado não surge, magicamente, do nada. Ele constitui uma unidade do ato de comunicação, um dos elos de uma corrente de outros enunciados, complexamente organizados. Em outras palavras, ao produzir um enunciado, o falante utiliza

${ }^{21}$ SHREK, PDI/DREAMWORKS.

${ }^{22}$ SHREK, PDI/DREAMWORKS, 2010. 
um sistema de linguagem e de enunciações preexistente, posicionando-se em relação a ele $e^{23}$.

Além desse perfil masculino autoritário ainda muito presente nos dias atuais, a sociedade contemporânea viu surgir também novos fenômenos comportamentais, e o metrossexual é um deles. A metrossexualidade designa um tipo de comportamento que surgiu no final dos anos 1990 para designar homens demasiadamente vaidosos. De acordo com Lisiane Ethur, "'metrossexual' é resultado da união das palavras Metropolitano e Sexual, constituindo uma gíria que identifica um homem urbano excessivamente preocupado com sua aparência e extremamente atento às tendências da moda e dos novos produtos masculinos lançados no mercado"24. Essas características revelam a ruptura com alguns estereótipos associados à masculinidade e a inserção de um traço sintonizado com as novas relações estabelecidas entre homens e mulheres.

Em Shrek 2, um personagem com essas características é apresentado ao público: o Príncipe Encantado, um tipo bastante peculiar que, atrasado no intento de salvar a princesa, vai em busca de Fiona no quarto mais alto da torre mais alta depois de ter, supostamente, enfrentado uma série de intempéries como ventos terríveis e um deserto escaldante, mas só encontra o lobo mau vestido de vovozinha, na cama da princesa, lendo o livro dos três porquinhos.

Encantado foge, assim como os outros personagens masculinos presentes nos filmes, do modelo convencional de príncipe, ele é declaradamente metrossexual, usa uma rede por baixo do capacete para manter os cabelos alinhados, usa gloss, desodorante bucal, polainas cor de rosa, faz as sobrancelhas, e sua mãe, a Fada Madrinha, é quem ainda penteia seus cabelos, preocupações e cuidados que não são comuns em personagens masculinos convencionais. É um personagem característico da pósmodernidade, na definição de Stuart Hall (2006), pois mostra-se múltiplo e não se pode atribuir a ele uma identidade fixa, essencial e unificada. Além do que evidencia uma mudança no comportamento assumido pelos homens no mundo contemporâneo, que estão cada vez mais preocupados em cuidar da aparência.

Por se tratar de um produto midiático que preza pela ironia, também percebemos que Encantado é muitas vezes ridicularizado por apresentar tais comportamentos e hábitos que tradicionalmente eram considerados preocupações estritamente femininas, como na cena final do segundo filme em que Shrek the diz: "Gostei muito dessa tua malha (se referindo à roupa usada pelo príncipe), onde comprou tinha para homem também?"

\footnotetext{
${ }^{23}$ SPINK, Mary Jane; MEDRADO, Benedito. Produção de sentido no cotidiano: uma abordagem teórico-metodológica para análise das práticas discursivas. In: SPINK, Mary Jane (org). Práticas discursivas e produção de sentidos no cotidiano. Rio de Janeiro: Centro Edelstein de Pesquisas sociais, 2013, p. 28.

24 ETHUR, Lisiane. Metrossexualidade. Disponível em: <http://www.revistasaudeinterativa.com.br/artigos/ed56/Metrossexualidade.pdf. >. Acesso em 3 jun. 2013.
} 
A sua caracterização representa uma desconstrução da figura do príncipe dos contos de fadas literários e do cinema, como um homem virtuoso e cheio de boas intenções. Encantado se posiciona como um antagonista nos filmes e todas as suas atitudes convergem para a busca de poder, prestígio e conforto. Ele oscila durante os filmes entre um garoto mimado pela mãe e um quase vilão, mas seus planos sempre dão errado. É narcisista e se auto-elogia todo o tempo. Em uma apresentação teatral, por exemplo, ele descreve a si próprio cantando: "eu sou capaz, sou forte sem igual, viril, veloz, cabelo angelical"25. Encantado utiliza adjetivos que na vida cotidiana são associados à identidade masculina e à feminina, o que mais uma vez o coloca como um personagem multifacetado. E ele desperta o interesse tanto da transgênera Dóris como da princesa Rapunzel.

O Burro tem a função de personagem articulador da trama. Além de ser bastante pitoresco por desenvolver longos monólogos irritando a todos com seu falatório, dá grandes lições sobre caráter, amizade e respeito retomando uma das funções primordiais das fábulas que é a transmissão de ensinamentos:

Burro: Sabe, com você é sempre "eu, eu, eu". Pois adivinhe, agora é a minha vez. Então cala a sua boca e presta atenção. Você é mau comigo, me insulta, não liga para nada do que eu faço. Está sempre me empurrando pra lá, empurrando pra cá.

Shrek: Ah, é? Se eu te tratei tão mal, por que é que voltou pra cá?

Burro: Porque é o que faz um amigo, ele perdoa o outro ${ }^{26}$.

A relação entre o Burro e o Dragão Fêmea é muito peculiar, ainda mais porque o dragão não possui fala e demonstra seus sentimentos apenas por meio dos gestos. E há, aí, também, uma subversão dos papéis tradicionais, pois é ela quem assedia o Burro:

Outro personagem masculino que chama a atenção é Lorde Farquaad. É uma pessoa egocêntrica com uma ideia fixa em possuir um reino perfeito, e por isso promove uma limpeza social para excluir de suas terras todas as criaturas mágicas. Ele tem também uma obsessão em ser rei e, para tanto, pretende se casar com alguma princesa, qualquer uma, a fim de adquirir o título. Assim, a sua opção por Fiona como esposa acontece de forma aleatória. A escolha da princesa ocorre por meio de um espelho mágico, cuja voz e performance se parecem com as de um apresentador de programas televisivos, e é quem apresenta três opções de esposas ao Lorde: Cinderela, Branca de Neve e Fiona e suas respectivas habilidades, hobbies e características físicas.

Observamos no filme que os personagens masculinos com títulos de nobreza: Lorde Farquaad, Príncipe Encantado e Rei Harold são representados como pessoas mesquinhas e sem escrúpulos. O mesmo acontece com Rumpestilschen quando se torna rei de Tão Tão Distante. Essa construção além

\footnotetext{
${ }^{25}$ SHREK, PDI/DREAMWORKS. 2007.

${ }^{26}$ SHREK, PDI/DREAMWORKS, 2001.
} 
de ser uma forma de crítica aos que representam cargos de poder, acaba funcionando também como uma maneira de desautorizar os centros.

Notamos ainda que esses personagens costumam buscar 0 relacionamento com as mulheres como forma de legitimar seu poder ou posição social. Assim temos que Farquaad quer se casar com Fiona pelo único motivo de se tornar rei; Príncipe Encantado deseja o mesmo, mas como não possui 0 seu próprio reino pretende herdar o trono do pai de Fiona. E Harold, que na verdade é um sapo transformado em humano por uma negociata com a Fada Madrinha, conseguiu seu título de nobreza após se casar com a rainha Lílian. Nesse sentido, o feminino se configura como objeto legitimador do poder masculino.

É possível perceber que todos esses personagens masculinos desconstroem a representação idealizada que tradicionalmente foi difundida nos contos de fadas e também nas animações cinematográficas. Com exceção de Shrek, eles não são fortes, não têm interesse em salvar o reino e tampouco a mocinha. Este modelo de masculinidade contrapõe-se ao que predominou até o final do século $X X$, reforçado inclusive pela difusão no cinema de imagens de homens dotados de uma força descomunal ou poderes sobrehumanos como do Super-Homem, Rambo, Robocop e os vários Exterminadores do Futuro, como salienta Eliane Teixeira Lopes27, e também pelas histórias encantadas da Disney, onde o príncipe-herói sempre aparece para ajudar a mocinha em apuros.

É na contramão dessa lógica que os personagens masculinos nos filmes Shrek são construídos, criticando as masculinidades e as representações que tradicionalmente se fizeram dela. Assim, Shrek, que representa os marginais, não se molda aos padrões de beleza e comportamento estabelecidos para um príncipe, constantemente mostra suas fragilidades, e não aceita se submeter às normas de boas maneiras da realeza, prefere seu pântano e despreza a forma de viver e agir da nobreza, com essa postura ele desqualifica o centro. 0 Príncipe Encantado aparece em uma versão metrossexual e não se pode atribuir a ele uma identidade sexual fixa; O Lobo Mau não sustenta sua imagem viril e ameaçadora, mas se veste de vovozinha em todos os filmes da saga; e o Burro faz o tipo sensível e sentimental. Com isso, o sujeito universal masculino é descentrado, destruindo o referente e trazendo os que estavam às margens para o interior do discurso.

Essa multiplicidade de representações masculinas e a desconstrução do príncipe como dotado de uma única identidade que falava em nome de todos os homens, aponta para o descentramento do sujeito moderno. E para isso, como ressalta Stuart Hall ${ }^{28}$, o movimento feminista teve grande contribuição, ao questionar o privado e o público, abrindo novas arenas da vida social que envolviam a sexualidade, a família, a divisão das tarefas domésticas e o cuidado com os filhos.

\footnotetext{
${ }^{27}$ LOPES, Eliane Teixeira. Prefácio - Vá ao cinema! In: TEIXEIRA, Inês Assunção de Castro; LOPES, José de Sousa Miguel (orgs). A mulher vai ao cinema. Belo Horizonte: Autêntica, 2008.

${ }^{28} \mathrm{HALL}$, Stuart. $A$ identidade cultural na pós-modernidade. Rio de Janeiro: DP\&A editora, 2006.
} 
Assim, "aquilo que começou como um movimento dirigido à contestação da posição social das mulheres expandiu-se para incluir a formação das identidades sexuais e de gênero"29. O movimento "também enfatizou, como uma questão política e social, o tema da forma como somos formados e produzidos como sujeitos generificados. Isto é, ele politizou a subjetividade, a identidade e o processo de identificação (como homens/mulheres, mães/pais, filhos/filhas) $)^{\prime \prime 30}$.

\section{Considerações finais}

Quando traçamos o percurso dos estudos feministas ao longo da história tomamos conhecimento de como o gênero é construído e reconstruído constantemente e através das mais variadas tecnologias. Dessa percepção surgiu o questionamento sobre as imagens transmitidas pelo cinema destinado às crianças e os discursos de subjetivação contidos nele, por isso os estudos de gênero e os escritos feministas foram imprescindíveis como aportes teóricometodológicos na pesquisa das nossas fontes.

Foi possível observar que os filmes, ao construírem as representações masculinas e femininas contemporâneas, se preocuparam em mostrar as contradições, dilemas e fraquezas dos personagens, e isso os aproximou mais dos seres humanos reais no tocante aos sentimentos e atitudes, com defeitos e qualidades. A diversificação nas representações e nos comportamentos adotados por personagens femininos e masculinos fez com que uma gama maior de espectadores pudesse se identificar, e isso pode ser entendido também como uma estratégia da lógica de mercado que busca atingir públicos cada vez maiores em diversos países.

Porém, vimos também que quando os homens são associados a características consideradas femininas como delicadeza e vaidade, e a serviços pretensamente desempenhados por mulheres como cuidar dos filhos e dos serviços domésticos, isso é considerado algo pejorativo que interfere na sua masculinidade e na imagem diante de outros homens.

Nosso objetivo, neste artigo, foi elucidar como essas tecnologias tão difundidas e acessíveis para variados públicos se constituem em poderosos difusores e construtores de sentidos sobre os gêneros no nosso cotidiano e instrumentos de pedagogização, que podem ser utilizados tanto para reforçar como para desconstruir os essencialismos e estereótipos baseados no sexo biológico.

Os feminismos atuam em uma luta constante. É claro que existem retrocessos e obstáculos diários, e para superá-los os estudos de gênero estão a postos problematizando e denunciando os mecanismos de submissão que se reinventam e atuam de forma sutil tentando aplacar as conquistas alcançadas

${ }^{29}$ Id. Ibidem, p. 45-46.

${ }^{30}$ Id. Ibidem, p. 45. 
pelas mulheres. Mas avanços também são perceptíveis. $E$, no tocante ao cinema de animação, notamos que cada vez mais surgem personagens que desconstroem os essencialismos e rótulos atribuídos social e biologicamente.

\section{Sobre as autoras}

Cláudia Maia é doutora em História. Professora da Universidade Estadual de Montes Claros (Unimontes). Bolsista BIPDT/Fapemig.

Renata Santos Maia é mestre em História Social pela Universidade Estadual de Montes Claros (Unimontes). Professora de Ensino médio.

Artigo recebido em 23 de setembro de 2014. Aprovado em 19 de novembro de 2014. 